\title{
Throughfall and temporal trends of rainfall redistribution in an open tropical rainforest, south-western Amazonia (Rondônia, Brazil)
}

\author{
S. Germer ${ }^{1}$, H. Elsenbeer ${ }^{1}$, and J. M. Moraes $^{2}$ \\ ${ }^{1}$ Institute of Geoecology, University of Potsdam, Potsdam, Germany \\ ${ }^{2}$ CENA, University of São Paulo, Piracicaba, S.P., Brazil
}

Received: 9 November 2005 - Published in Hydrol. Earth Syst. Sci. Discuss.: 19 December 2005

Revised: 9 March 2006 - Accepted: 17 March 2006 - Published: 2 June 2006

\begin{abstract}
Throughfall volumes and incident rainfall were measured between 23 August and 2 December 2004 as well as from 6 January to 15 April 2005 for individual rain events of differing intensities and magnitudes in an open tropical rainforest in Rondônia, Brazil. Temporal patterns of throughfall spatial variability were examined. Estimated interception was compared to modeled interception obtained by applying the revised Gash model in order to identify sources of throughfall variability in open tropical rainforests.

Gross precipitation of 97 events amounted to $1309 \mathrm{~mm}$, $89 \pm 5.6 \%$ (S.E.) of which reached the forest floor as throughfall. The redistribution of water within the canopy was highly variable in time, which we attribute to the high density of babassu palms (Orbignya phalerata), their seasonal leaf growth, and their conducive morphology. We identified a 10-min rainfall intensity threshold of $30 \mathrm{~mm} \mathrm{~h}^{-1}$ above which interception was highly variable. This variability is amplified by funneling and shading effects of palms. This interaction between a rainfall variable and vegetation characteristics is relevant for understanding the hydrology of all tropical rainforests with a high palm density.
\end{abstract}

\section{Introduction}

Interception of rainwater accounts for that amount of rainfall intercepted by the canopy, which is evaporated during events or after rainfall ceased. The remaining rainfall reaches the forest floor either as throughfall or stemflow. As intercepted water does no longer participate in near-surface hydrological processes (Savenije, 2004), precise knowledge of its magni-

Correspondence to: S. Germer

(sgermer@uni-potsdam.de) tude is essential for our understanding and modeling of these processes.

Interception studies were conducted in different climatic regions and forest types, such as temperate broad-leaf (Xiao et al., 2000; Liu et al., 2003) and conifer forests (Huber and Iroume, 2001; Link et al., 2004), lowland tropical rainforests (Dykes, 1997; Schellekens et al., 1999), and tropical montane forests (Holder, 2004; Munishi and Shear, 2005). Interception is estimated by applying a variety of empirical, physically-based, and analytical models. The physicallybased Rutter model (Rutter et al., 1971) and the analytical Gash model (Gash, 1979; Gash et al., 1995) are two of the most widely used interception models. Estimates of interception in tropical forests are influenced by a high spatial variability of throughfall (Jackson, 1971; Lloyd and Marques, 1988). This variability seems to be caused by canopy features such as leaf or woody frame properties (Herwitz, 1987). Hall (2003) showed that there is a positive correlation between LAI (leaf area index) and interception, but that interception can vary broadly due to different leaf properties for canopies with the same LAI. Other studies focused on the effect of differing percentage of canopy cover, but found only a weak relationship between throughfall and canopy cover (Tobón Marin et al., 2000; Loescher et al., 2002). Others investigated throughfall amount as a function of distance to tree trunks (Ford and Deans, 1978; Beier et al., 1993; Schroth et al., 1999), but found this distance to be a poor predictor (Keim et al., 2005). Herwitz and Slye (1992) found that neighboring canopy tree crowns can receive different depths of gross rainfall, resulting in a variable pattern of throughfall due to inclined rainfall and shading effects of nearby trees.

Keim et al. (2005) investigated the temporal persistence of spatial patterns of throughfall and found them to be stable for three forest stands with different canopy complexities

Published by Copernicus GmbH on behalf of the European Geosciences Union. 
in the Pacific Northwest, USA. Details of canopy interception, in particular within the tropics, are still not well understood. To our knowledge temporal variability of spatial patterns of throughfall in tropical rainforests has not been studied before. The results of such a study, however, are expected to lead to a better understanding of the interception process within these environments, in particular for event based studies conducted over several month.

Our objectives were a) to quantify throughfall in an open tropical rainforest with high palm density, b) to identify any temporal patterns of throughfall spatial variability, and c) to determine the conditions under which this variability complicates the estimation of interception.

\section{Material and methods}

\subsection{Site and climate}

The study site Rancho Grande is located about $50 \mathrm{~km}$ south of Ariquemes $\left(10^{\circ} 18^{\prime} \mathrm{S}, 62^{\circ} 52^{\prime} \mathrm{W}, 143 \mathrm{~m}\right.$ a.s.1.) in the Brazilian state of Rondônia, which is situated in the southwestern part of the Amazon basin.

The area is part of a morphostructural unit known as "Southern Amazon Dissected Highlands" (Planalto Dissecado Sul da Amazônia, Peixoto de Melo et al., 1978), which is characterized by a very pronounced topography with an altitudinal differential of up to $150 \mathrm{~m}$ : remnant ridges of Precambrian basement rock, made up of gneisses and granites of the Xingu (Leal et al., 1978) or Jamari Complex (Isotta et al., 1978), are separated by flat valley floors of varying width. Soil orders associated with this morphostructural unit are Ultisols, Oxisols, and Inceptisols and Entisols (Soil Survey Staff, 1999) on steep slopes and along streams, respectively.

The vegetation at this terra firme study site consists of primary open tropical rainforest (Floresta Ombrófila Aberta) with a large number of palm trees. In Rondônia open tropical rainforest amounts to $55 \%$ of the total vegetation area (Pequeno et al., 2002). It is characterized by a discontinuous upper canopy of up to $35 \mathrm{~m}$ height with emergent trees up to $45 \mathrm{~m}$ tall, permitting the sun light to reach the understory and thereby facilitating a dense undergrowth. Roberts et al. (1996) determined a LAI of 4.6 for an open tropical rainforest at the ecological reserve "Reserva Jaru" about $100 \mathrm{~km}$ east of Rancho Grande, compared to a LAI of 6.1 for a dense tropical rainforest measured $60 \mathrm{~km}$ north from Manaus. For trees with DBH (diameter at breast height) $>5 \mathrm{~cm}$, the tree density is $813 \mathrm{ha}^{-1}$ including 108 palms, and $520 \mathrm{ha}^{-1}$ for $\mathrm{DBH}>10 \mathrm{~cm}$, including 81 palms. Among the 94 species with $\mathrm{DBH}>5 \mathrm{~cm}(89$ species with $\mathrm{DBH}>10 \mathrm{~cm})$ the most abundant are Pama verdadeira (Brosimum gaudichaudii, Moraceae) and Breu rosa (Protium sp., Burseraceae). The most common palm species in this region are Paxiuba bariguda (Iriartea deltoidea), followed by the babassu palm (Orbignya phalerata, local name: babaçu) with a density of 36 full-grown and 115 young individuals per hectare.

The climate of Rondônia is tropical wet and dry (Köppen's Aw). The mean annual temperature is about $27^{\circ} \mathrm{C}$. Variations in mean monthly temperature maxima and minima are on average $12.4^{\circ} \mathrm{C}$, ranging from $10.6^{\circ} \mathrm{C}$ in March to $15.7^{\circ} \mathrm{C}$ in August. Mean annual precipitation is $2300 \mathrm{~mm}$ with a marked dry period from July through September. On average, 144 days with rainfall are registered per year, 133 of which fall into the rainy season lasting from October to June. On average, 20 rain days per month occur during the peak of the rainy season, from December through March. The seasonal variation in average daily relative humidity levels ranges from $65 \%$ in July to $80 \%$ in December (averages of the years 1984-2003, Schmitz, personal communication).

\subsection{Experimental design and data analysis}

Throughfall and gross rainfall were measured on event basis between 23 August and 2 December 2004 as well as from 6 January to 15 April 2005, whilst stemflow was measured from 27 January up to 20 March 2005.

\subsubsection{Gross rainfall}

A tipping bucket rain gauge (Hydrological Services P/L, Liverpool Australia) with a resolution of $0.254 \mathrm{~mm}$ and a Campbell logger recorded 5-min rainfall intensity values on a pasture about $400 \mathrm{~m}$ from the forest. In order to characterize events, we selected for each event the contiguous 10 and 60 min with the highest rainfall intensities to calculate the maximum $10 \mathrm{~min}$ intensities $\left(I_{10} \mathrm{max}\right)$ and maximum $60 \mathrm{~min}$ intensities $\left(I_{60} \max \right)$ in $\mathrm{mm} \mathrm{h}^{-1}$. We did not include events with a duration of less than 10 and $60 \mathrm{~min}$, respectively.

In addition, incident rainfall was measured with three trough-type collectors. One was read manually and the other two were connected to one single tipping bucket logged by a Hobo Event Logger (Onset) with a resolution of $0.51 \mathrm{~mm}$. The collectors, installed on support $1 \mathrm{~m}$ above ground, were made out of $150 \mathrm{~mm}$ diameter PVC pipes, which were connected via flexible tubes to $20 \mathrm{~L}$ plastic canisters. The total collecting area per collector was $980 \mathrm{~cm}^{2}(70 \mathrm{~cm} * 140 \mathrm{~cm})$. To avoid splash losses a orifice with a width $(70 \mathrm{~mm})$ smaller than the diameter was cut out of the PVC pipes. The rainfall quantity data of the trough-type collectors was only used to calibrate the trough collector volumes with volumes measured by the automatic weather station (calibration factor: $1.1, R^{2}=0.99$ ).

In order to qualify for an event, at least $0.5 \mathrm{~mm}$ of rainfall must have been recorded in half an hour. Events are separated by at least two hours without rain. 


\subsubsection{Throughfall}

Throughfall quantities per event were measured manually with 20 collectors (10 collectors between 26 August and 1 September 2004) as described above, which were leveled and cleaned of litter after each event. The measured throughfall was corrected by the calibration factor described previously.

The collectors were distributed throughout a heavily instrumented catchment with a maximum distance of $170 \mathrm{~m}$ between collectors. Their sites were chosen at random, but with a view towards minimizing disturbance instead of a strictly random distribution with random relocation of collectors (Lloyd and Marques, 1988); Helvey and Patric (1965) recommended such a random relocation, but only for interception studies on a weekly or monthly basis but not on an event basis as in our case. Even so, we attempted to cover the small-scale variability in vegetation.

Two hours after every event or alternatively the next morning for events which ended after 09:00 PM, we emptied the collectors and quantified the throughfall with graduated cylinders of three different sizes. For events with less or equal to $5 \mathrm{~mm}$, between 5 and $15 \mathrm{~mm}$ and events bigger or equal to $15 \mathrm{~mm}$ graduated cylinders of $100 \mathrm{ml}, 500 \mathrm{ml}$ and $1000 \mathrm{ml}$ were used, respectively.

Throughfall values per event were tested for normality using the Shapiro-Wilk-Test (Shapiro and Wilk, 1965). As throughfall was not normally distributed for $24 \%$ of the events, the median of all collectors was used to estimate throughfall per event.

To determine whether high or low throughfall areas persist between events, Keim et al. (2005) used the standardized throughfall, $\tilde{T}_{i, j}$, for each sample point $i$ :

$\tilde{T}_{i, j}=\frac{T_{i, j}-\bar{T}_{j}}{s_{T_{j}}}$,

where $T_{i, j}$ is the throughfall at sampling point $i$ of event $j$, $\bar{T}_{j}$ is the mean throughfall for a given event $j$, and $s_{T_{j}}$ its standard deviation. We used the same equation, but with the median and its standard deviation (Sachs, 1984) instead of the mean and its standard deviation.

\subsubsection{Stemflow}

Stemflow or the rainfall diverted to trunk, $p_{t}$, was collected along the catchment perimeter, which resulted in a maximum distance between sample trees of $300 \mathrm{~m}$. Aluminum collectors with an inner diameter of 3-4 cm were fitted around trunks at breast hight (1.3 $\mathrm{m}$ above the forest floor) in a downward spiral. Polythene inlays were sealed to the trunks, and flexible tubes diverted the water to canisters standing on the forest floor. Stemflow was measured for 24 randomly selected trees in three different DBH classes $(5-10 \mathrm{~cm}, 10-$ $20 \mathrm{~cm}$ and $>20 \mathrm{~cm}$ ) and for one palm class with 8 large aborescent babassu palms. The stemflow, $S_{j}$, per class $j$ in mm for individual storms $n$ was determined using the equation applied by Hanchi and Rapp (1997):

$\left[S_{j}\right]_{n}=\left[v_{j}\right]_{n} * F_{j} * 10^{-4}$,

where $v_{j}$ is the median stemflow in liter per class $j$ and event $n$ and $F_{j}$ is the number of trees per hectare and class $j$. The stemflow percentage of incident rainfall was then calculated for each class and each storm. The median stemflow percentages per class were summed up, to obtain median stemflow for our study site. The instrumentation and measurement procedure of stemflow is described in more detail in a parallel work Werther $(2005)^{1}$. For our study, we used an average value for stemflow of $8.0 \%$ of incident rainfall for all events.

\subsection{The revised Gash model}

\subsubsection{Model description}

In cases of low data availability a simple regression equation is often used to describe interception:

$I=a P_{G}+b$,

where $I$ is the interception in mm of incident rain, $P_{G}$ is the gross rainfall and $a$ and $b$ are the regression coefficients. Unlike the regression equation, the original Gash model (Gash, 1979 ) is based on a simple but realistic approach to describe the interception process, and yet is characterized by a low data requirement. The revised Gash model (Gash et al., $1995)$ is an adaptation of the original model to account for stands with sparse canopies.

The original and the revised Gash model assume that the two major factors which control the evaporation of intercepted rainfall are 1) the duration of evaporation from the saturated canopy per event plus the associated evaporation rate and 2) the canopy saturation capacity as well as the number of times the saturated canopy is dried out completely after an event.

The amount of rainfall needed to completely saturate the canopy, $P_{G}^{\prime}$, is expressed by Gash et al. (1995) as

$P_{G}^{\prime}=\frac{-\bar{R} S_{c}}{\bar{E}_{c}} \ln \left[1-\frac{\bar{E}_{c}}{\bar{R}}\right]$,

where $\bar{R}$ is the mean rainfall rate and $\bar{E}_{c}$ is the mean evaporation rate from the canopy. The canopy capacity per unit area of cover, $S_{c}=S / c$, is the amount of water remaining on the saturated canopy after rainfall and throughfall ceased.

To get an estimate for the mean rainfall rate falling onto the saturated canopy, $\bar{R}$ is calculated for all hours exceeding a certain threshold of hourly rainfall. We adopted a value of $0.5 \mathrm{~mm} \mathrm{~h}^{-1}$ in accordance to Gash (1979), Lloyd et al. (1988) and Schellekens et al. (1999).

\footnotetext{
${ }^{1}$ Werther, L.: Stemflow in an open tropical rainforest in Rondônia, Brazil, M.Sc. Thesis, University of Potsdam, Potsdam, unpublished, 2005.
} 
Table 1. The components of the revised interception model according to Gash (1995).

\begin{tabular}{lc}
\hline Component of interception & Formulation of components \\
\hline For $m$ small storms, insufficient to saturate the canopy & $c \sum_{j=1}^{m} P_{G, j}$ \\
Wetting up the canopy, for n storms $>P_{G}^{\prime}$ which saturate the canopy & $n c P_{G}^{\prime}-n c S_{c}$ \\
Evaporation from saturation until rainfall ceases & $\frac{c \overline{E_{c}}}{\bar{R}} \sum_{j=1}^{n}\left(P_{G, j}-P_{G}^{\prime}\right)$ \\
Evaporation after rainfall ceases & $n c S_{c}$ \\
$\begin{array}{l}\text { Evaporation from trunks, for } q \text { storms }>S_{t} / p_{t}, \text { which saturate the } \\
\text { trunks and for } n-q \text { storms, which do not }\end{array}$ & $q S_{c}+p_{t} \sum_{j=1}^{n-q} P_{G, j}$ \\
\hline
\end{tabular}

Interception is calculated in several steps by dividing the rainfall events into three phases. The first considers the stage before the canopy is saturated, with $P_{G}<P_{G}^{\prime}$, the second covers the part of the rainfall event when the canopy is saturated, and the last stage refers to the evaporation after the rain ceased. This trichotomy leads towards the five equations summarized in Table 1. Total interception is calculated as the sum of these different components. According to Gash (1979) and Lloyd et al. (1988), we calculated mean rainfall intensity for all hours with $P_{G}$ greater $0.5 \mathrm{~mm} \mathrm{~h}^{-1}$; however, the difference to all hours of rainfall is not great due to the short and intense rainfall events typical for this climate.

Gash (1979) suggested to determine $\bar{E}_{c}$ by regressing interception on gross rainfall, as the regression coefficient provides $\bar{E}_{c} / \bar{R}$. Due to the high varaiability of throughfall, $\bar{E}_{c}$ could not be determined by this method in our study. Instead we adopted the value of $0.21 \mathrm{~mm} \mathrm{~h}^{-1}$ found by Lloyd (1988) for central Amazonia, which appears to be typical for tropical forests (Hall, 2003).

\subsubsection{Forest parameters}

Canopy interception parameters are usually estimated by gross rainfall and throughfall data collected on an event or weekly basis (Leyton et al., 1967; Gash and Morton, 1978; Rowe, 1983; Jetten, 1996), compensating short-term variability. The canopy capacity is often determined by the method of Leyton et al. (1967), where in a plot of throughfall versus rainfall a line with a slope of one is drawn passing through events with maximum throughfall. The intercept with the gross rainfall axis is interpreted as the value for canopy storage.

This method however, is not suitable for forests with a high spatial variability of throughfall. Instead, we employed a slightly modified version of the method of Lloyd et al. (1988). For each collector, we regressed throughfall on gross precipitation for events with $1.5 \leq P_{G} \leq 15.0 \mathrm{~mm}$. Because of outliers and high-leverage points, we used a robust regression method based on Tukey's beweight (Hoaglin et al., 2000). To ensure the drying out of the canopy, only events separated by dry periods of at least $6 \mathrm{~h}$ were considered in these calculations. It is assumed that for the small events used for this approach evaporation can be ignored. Stemflow, however, can't be neglected for this kind of forest (Werther, $2005)^{1}$. In contrast to Lloyd et al. (1988), we defined for each collector a regression of throughfall over the difference of gross rainfall and the stemflow proportion

$T=a\left(P_{G}-p_{t} * P_{G}\right)+b$

with $a$ as the slope of the regression and $b$ the intercept. The canopy capacity per ground area, $S$, is determined as the mean intercept of the regression lines with the $\mathrm{x}$-axis. The standard deviation of $S$ was calculated using the mean standard deviation of $b$ for all collectors.

We estimated the free throughfall coefficient, $p$, with digital photographs taken on January 15, 2005. At each of three equidistant points in the catchment, we laid out two 10-m long transects normal to each other, along which we took black-and-white pictures of the canopy, with a camera mounted on a level, in one meter intervals, resulting in a total of 60 pictures. An image editing program was used to find the center of the images to verify if the center was covered by the canopy or not, which yielded a proportion of canopy coverage, $c$, and hence the free throughfall coefficient $p=1-c$.

\section{Results and discussion}

\subsection{Gross rainfall}

The total incident rainfall at Rancho Grande from August 2004 to July 2005 was $2286 \mathrm{~mm} \mathrm{a}^{-1}$, being in line with the mean annual rainfall amount of the previous 20 years of $2300 \mathrm{~mm} \mathrm{a}^{-1}$. The month of August, however, was far wetter than the average (Fig. 2), due to an early start of the rainy season. In addition, April and June were much drier than the respective 20-year average.

We collected 97 events over the two monitoring periods (Aug-Dec and Jan-Apr), with a total of gross precipitation of $1309 \mathrm{~mm}$. Rainfall intensity for all measured 


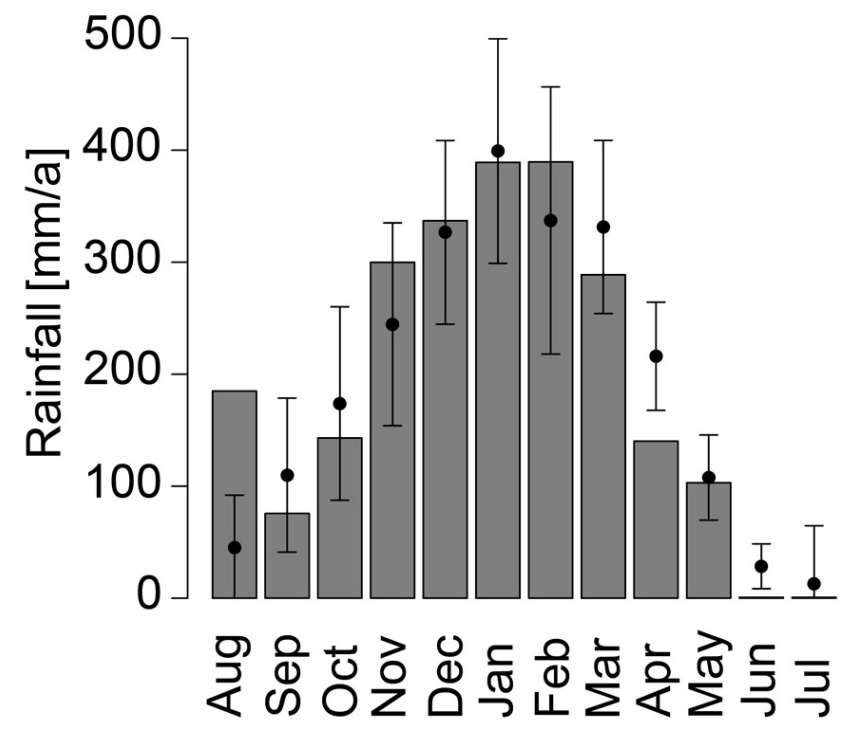

Fig. 1. Monthly rainfall data from August 2004 to July 2005. The solid circles and the vertical lines are the mean and standard error, respectively for the period 1984-2003.

events and all hours with intensities $>0.5 \mathrm{~mm} \mathrm{~h}^{-1}$ averaged $6.66 \mathrm{~mm} \mathrm{~h}^{-1}$. The highest values for $\mathrm{I}_{10} \max$ and $\mathrm{I}_{60} \max$ were $100.61 \mathrm{~mm} \mathrm{~h}^{-1}$ and $57.91 \mathrm{~mm} \mathrm{~h}^{-1}$, respectively. Durations shorter than $1 \mathrm{~h}$ were found for $44 \%$ of the events.

\subsection{Throughfall}

All throughfall results are summarized in Table 2. A sample size $\mathrm{n}$ of less than 20 (less than 10 for events between 26 August and 1 September 2004) implies loss of data for individual collectors. The total measured throughfall volume of the whole study period was $1175 \mathrm{~mm}$ or $89.8 \pm 5.6 \%$ (S.E.) of incident rainfall. This percentage is in line with results of other studies. Ubarana (1996) reported $87 \%$ of observed total throughfall for Reserva Jaru site within about $100 \mathrm{~km}$ of our site. These values fall within the range of throughfall values reported for rainforests in the Amazon basin with 78-91\% (Lloyd and Marques, 1988; Elsenbeer et al., 1994; Filoso et al., 1999; Tobón Marin et al., 2000), in Asia of about 80\% (Sinun et al., 1992; Dykes, 1997) or Africa with 92-97\% (Chuyong et al., 2004).

For 18 events throughfall volumes of more than $100 \%$ of $P_{G}$ were measured and throughfall plus the proportional stemflow volumes of the incident rainfall exceeded rainfall volumes in 25 cases, resulting in negative values for interception. Despite two cases in August negative values did occur more frequently from November onwards. Since negative values for average interception per event can only be expected for some special forest types, e.g. mountain cloud forests (Holder, 2004), there is either an underestimation of rainfall or an overestimation of throughfall quantities for these events. Our own manual rainfall measurements next to

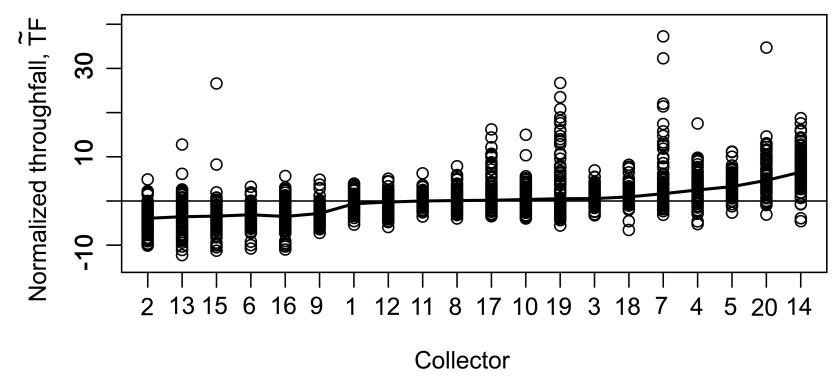

Fig. 2. Plot of normalized throughfall, $\tilde{T}$, for the whole period. Each circle represents the event throughfall volume at a single collector, normalized to zero median and unit variance for that event. The collectors are plotted on the horizontal axis and ranked by their means, $\tilde{T}$, which are connected by the black curve.

the automatic rain gauge, however, preclude the former possibility. Therefore, these negative values are likely to result from an effect induced by not only the spatial variability of throughfall, but also the temporal variability of throughfall in individual collectors as discussed hereafter.

Throughfall amounts vary highly among collectors due to drip points and caps above the collectors (Loescher et al., 2002). The plot of normalized throughfall, $\tilde{T}$ (Fig. 2) is ranked by mean $\tilde{T}$ per collector. Since each dot represents one throughfall observation at a single collector, the plot shows the temporal variability of throughfall for each collector. Several collectors registered frequently more (e.g. collectors 14 or 20) or less (e.g. collectors 2 or 13) than the median throughfall per event, as indicated by the deviation from the horizontal axis. None of the collectors deviated, however, persistently in either direction. The temporal variability in some of our collectors was up to three times as high as in others (e.g. collectors 7 and 19). In contrast to our results, Keim et al. (2005) found a much lower temporal variability for coniferous and deciduous stands in the Pacific Northwest, USA, which we attribute to the differences in homogeneity of the two forest types.

Figure 2 does not show whether the variability of single collectors is temporally stable. By plotting throughfall per event as a percentage of $P_{G}$ over time for each collector separately, a temporal trend in some of the collectors becomes evident. Figure 3 shows two impressive examples of this temporal variability of throughfall proportions, for two collectors, 2 and 19. For the latter, maximum throughfall percentages of over $300 \%$ were registered. In both cases, throughfall rises sharply from early October towards December. During the second study period (Jan-Apr), the same trend can be observed for collector no. 2 and a decreasing trend for collector no. 19. For both periods, collector no. 2 (Fig. 3a) shows a pattern only for large, high intensity events, while collector no. 19 (Fig. 3b) shows a pattern regardless of event size or intensity. The photographs in Fig. 3 were taken upright from the middle of the collectors, showing the canopy 
Table 2. Summary of events, $P_{G}$ : observed gross precipitation; $\bar{T}$ : median throughfall of $n$ collectors; $S$ : estimated stemflow; $I$ : interception; $n$ : number of collectors.

\begin{tabular}{|c|c|c|c|c|c|c|c|}
\hline Event & Date & $P_{G}(\mathrm{~mm})$ & $\bar{T}(\mathrm{~mm})$ & $\bar{T}$ in $\%$ of $P_{G}$ & $S(\mathrm{~mm})$ & $I(\mathrm{~mm})$ & $n$ \\
\hline 1 & $23 / 08 / 2004$ & 12.44 & 7.07 & 56.83 & 0.97 & 4.4 & 10 \\
\hline 2 & $26 / 08 / 2004$ & 1.77 & 2.12 & 119.77 & 0.14 & -0.49 & 10 \\
\hline 3 & $28 / 08 / 2004$ & 19.81 & 21.23 & 107.17 & 1.55 & -2.97 & 9 \\
\hline 4 & $29 / 08 / 2004$ & 4.82 & 3.44 & 71.37 & 0.38 & 1 & 10 \\
\hline 5 & $30 / 08 / 2004$ & 1.01 & 0.07 & 6.93 & 0.08 & 0.86 & 10 \\
\hline 6 & $01 / 09 / 2004$ & 6.09 & 3.67 & 60.26 & 0.48 & 1.94 & 10 \\
\hline 7 & $16 / 09 / 2004$ & 21.33 & 14.91 & 69.9 & 1.66 & 4.76 & 19 \\
\hline 8 & $25 / 09 / 2004$ & 27.17 & 22.76 & 83.77 & 2.12 & 2.29 & 19 \\
\hline 9 & $28 / 09 / 2004$ & 2.28 & 0.22 & 9.65 & 0.18 & 1.88 & 20 \\
\hline 10 & 29/09/2004 & 7.87 & 2.46 & 31.26 & 0.61 & 4.8 & 20 \\
\hline 11 & $04 / 10 / 2004$ & 2.03 & 1.41 & 69.46 & 0.16 & 0.46 & 19 \\
\hline 12 & 07/10/2004 & 25.65 & 18.97 & 73.96 & 2 & 4.68 & 20 \\
\hline 13 & $12 / 10 / 2004$ & 31.24 & 27.28 & 87.32 & 2.44 & 1.52 & 20 \\
\hline 14 & $14 / 10 / 2004$ & 3.81 & 0.94 & 24.67 & 0.3 & 2.57 & 20 \\
\hline 15 & $15 / 10 / 2004$ & 3.81 & 1.56 & 40.94 & 0.3 & 1.95 & 20 \\
\hline 16 & 19/10/2004 & 0.76 & 0.24 & 31.58 & 0.06 & 0.46 & 20 \\
\hline 17 & $21 / 10 / 2004$ & 33.27 & 24.48 & 73.58 & 2.6 & 6.19 & 20 \\
\hline 18 & $24 / 10 / 2004$ & 10.41 & 8.89 & 85.4 & 0.81 & 0.71 & 20 \\
\hline 19 & $27 / 10 / 2004$ & 4.31 & 2.72 & 63.11 & 0.34 & 1.25 & 20 \\
\hline 20 & $30 / 10 / 2004$ & 19.81 & 17.3 & 87.33 & 1.55 & 0.96 & 20 \\
\hline 21 & $31 / 10 / 2004$ & 3.04 & 2.42 & 79.61 & 0.24 & 0.38 & 20 \\
\hline 22 & $02 / 11 / 2004$ & 3.81 & 2.49 & 65.35 & 0.3 & 1.02 & 20 \\
\hline 23 & $03 / 11 / 2004$ & 0.5 & 0.08 & 16 & 0.04 & 0.38 & 20 \\
\hline 24 & $04 / 11 / 2004$ & 45.46 & 43.45 & 95.58 & 3.55 & -1.54 & 20 \\
\hline 25 & $10 / 11 / 2004$ & 30.98 & 36.07 & 116.43 & 2.42 & -7.51 & 20 \\
\hline 26 & $11 / 11 / 2004$ & 6.35 & 4.59 & 72.28 & 0.5 & 1.26 & 20 \\
\hline 27 & $14 / 11 / 2004$ & 63.75 & 70.46 & 110.53 & 4.97 & -11.68 & 19 \\
\hline 28 & $17 / 11 / 2004$ & 23.62 & 29.81 & 126.21 & 1.84 & -8.03 & 20 \\
\hline 29 & $18 / 11 / 2004$ & 7.87 & 7.38 & 93.77 & 0.61 & -0.12 & 20 \\
\hline 30 & $20 / 11 / 2004$ & 30.98 & 39.61 & 127.86 & 2.42 & -11.05 & 20 \\
\hline 31 & $20 / 11 / 2004$ & 0.5 & 0.23 & 46 & 0.04 & 0.23 & 20 \\
\hline 32 & $22 / 11 / 2004$ & 10.41 & 7.41 & 71.18 & 0.81 & 2.19 & 20 \\
\hline 33 & $24 / 11 / 2004$ & 5.32 & 4.25 & 79.89 & 0.41 & 0.66 & 20 \\
\hline 34 & $25 / 11 / 2004$ & 0.5 & 0.32 & 64 & 0.04 & 0.14 & 20 \\
\hline 35 & $26 / 11 / 2004$ & 0.5 & 0.55 & 110 & 0.04 & -0.09 & 20 \\
\hline 36 & $28 / 11 / 2004$ & 5.84 & 4.33 & 74.14 & 0.46 & 1.05 & 20 \\
\hline 37 & $30 / 11 / 2004$ & 1.52 & 0.61 & 40.13 & 0.12 & 0.79 & 20 \\
\hline 38 & $11 / 01 / 2005$ & 35.3 & 35.82 & 101.47 & 2.75 & -3.27 & 20 \\
\hline 39 & $14 / 01 / 2005$ & 17.52 & 15.9 & 90.75 & 1.37 & 0.25 & 19 \\
\hline 40 & $14 / 01 / 2005$ & 6.85 & 6.89 & 100.58 & 0.53 & -0.57 & 20 \\
\hline 41 & $16 / 01 / 2005$ & 0.5 & 0.19 & 38 & 0.04 & 0.27 & 20 \\
\hline 42 & $18 / 01 / 2005$ & 1.01 & 0.69 & 68.32 & 0.08 & 0.24 & 20 \\
\hline 43 & $22 / 01 / 2005$ & 78.23 & 75.02 & 95.9 & 6.1 & -2.89 & 20 \\
\hline 44 & $24 / 01 / 2005$ & 23.11 & 18.83 & 81.48 & 1.8 & 2.48 & 20 \\
\hline 45 & $25 / 01 / 2005$ & 0.76 & 0 & 0 & 0.06 & 0.7 & 20 \\
\hline 46 & $26 / 01 / 2005$ & 1.01 & 0.29 & 28.71 & 0.08 & 0.64 & 20 \\
\hline 47 & $27 / 01 / 2005$ & 24.88 & 24.75 & 99.48 & 1.94 & -1.81 & 19 \\
\hline 48 & $28 / 01 / 2005$ & 6.09 & 6.37 & 104.6 & 0.48 & -0.76 & 20 \\
\hline 49 & $29 / 01 / 2005$ & 11.43 & 10.07 & 88.1 & 0.89 & 0.47 & 20 \\
\hline 50 & $30 / 01 / 2005$ & 4.57 & 4.58 & 100.22 & 0.36 & -0.37 & 20 \\
\hline 51 & $30 / 01 / 2005$ & 1.01 & 0.51 & 50.5 & 0.08 & 0.42 & 20 \\
\hline 52 & $31 / 01 / 2005$ & 29.46 & 20.14 & 68.36 & 2.3 & 7.02 & 20 \\
\hline 53 & $31 / 01 / 2005$ & 42.91 & 40.92 & 95.36 & 3.35 & -1.36 & 20 \\
\hline
\end{tabular}


Table 2. Continued.

\begin{tabular}{|c|c|c|c|c|c|c|c|}
\hline Event & Date & $P_{G}(\mathrm{~mm})$ & $\bar{T}(\mathrm{~mm})$ & $\bar{T}$ in $\%$ of $P_{G}$ & $S(\mathrm{~mm})$ & $I(\mathrm{~mm})$ & $n$ \\
\hline 54 & $04 / 02 / 2005$ & 15.24 & 4.75 & 31.17 & 1.19 & 9.3 & 20 \\
\hline 55 & $05 / 02 / 2005$ & 8.89 & 5.44 & 61.19 & 0.69 & 2.76 & 20 \\
\hline 56 & 06/02/2005 & 1.27 & 0.52 & 40.94 & 0.1 & 0.65 & 20 \\
\hline 57 & 08/02/2005 & 43.43 & 38.62 & 88.92 & 3.39 & 1.42 & 20 \\
\hline 58 & 09/02/2005 & 14.73 & 13.77 & 93.48 & 1.15 & -0.19 & 20 \\
\hline 59 & $11 / 02 / 2005$ & 37.84 & 24.34 & 64.32 & 2.95 & 10.55 & 20 \\
\hline 60 & $13 / 02 / 2005$ & 2.54 & 1.93 & 75.98 & 0.2 & 0.41 & 20 \\
\hline 61 & $15 / 02 / 2005$ & 2.03 & 1.54 & 75.86 & 0.16 & 0.33 & 20 \\
\hline 62 & $17 / 02 / 2005$ & 30.22 & 27.24 & 90.14 & 2.36 & 0.62 & 20 \\
\hline 63 & $17 / 02 / 2005$ & 4.57 & 3.66 & 80.09 & 0.36 & 0.55 & 20 \\
\hline 64 & $18 / 02 / 2005$ & 2.28 & 1.31 & 57.46 & 0.18 & 0.79 & 20 \\
\hline 65 & $19 / 02 / 2005$ & 30.48 & 24.07 & 78.97 & 2.38 & 4.03 & 20 \\
\hline 66 & $21 / 02 / 2005$ & 0.76 & 0.66 & 64.71 & 0.08 & 0.28 & 20 \\
\hline 67 & $21 / 02 / 2005$ & 23.36 & 24.03 & 102.87 & 1.82 & -2.49 & 20 \\
\hline 68 & $23 / 02 / 2005$ & 33.27 & 50.5 & 151.79 & 2.6 & -19.83 & 19 \\
\hline 69 & $24 / 02 / 2005$ & 3.04 & 0.57 & 18.75 & 0.24 & 2.23 & 20 \\
\hline 70 & $26 / 02 / 2005$ & 1.52 & 0.82 & 53.95 & 0.12 & 0.58 & 20 \\
\hline 71 & $27 / 02 / 2005$ & 31.75 & 24.39 & 76.82 & 2.48 & 4.88 & 20 \\
\hline 72 & $28 / 02 / 2005$ & 17.27 & 18.52 & 107.24 & 1.35 & -2.6 & 20 \\
\hline 73 & $01 / 03 / 2005$ & 8.12 & 5.74 & 70.69 & 0.63 & 1.75 & 20 \\
\hline 74 & 02/03/2005 & 11.68 & 13.86 & 118.66 & 0.91 & -3.09 & 20 \\
\hline 75 & $04 / 03 / 2005$ & 6.09 & 4.02 & 66.01 & 0.48 & 1.59 & 20 \\
\hline 76 & $05 / 03 / 2005$ & 57.66 & 61.56 & 106.76 & 4.5 & -8.4 & 20 \\
\hline 77 & 07/03/2005 & 6.09 & 1.67 & 27.42 & 0.48 & 3.94 & 20 \\
\hline 78 & 07/03/2005 & 3.04 & 1.65 & 54.28 & 0.24 & 1.15 & 20 \\
\hline 79 & $10 / 03 / 2005$ & 6.09 & 4.43 & 72.74 & 0.48 & 1.18 & 19 \\
\hline 80 & $11 / 03 / 2005$ & 2.79 & 1.72 & 61.65 & 0.22 & 0.85 & 20 \\
\hline 81 & $13 / 03 / 2005$ & 1.77 & 1.61 & 90.96 & 0.14 & 0.02 & 20 \\
\hline 82 & $14 / 03 / 2005$ & 21.84 & 20.37 & 93.27 & 1.7 & -0.23 & 20 \\
\hline 83 & $16 / 03 / 2005$ & 16.75 & 14.41 & 86.03 & 1.31 & 1.03 & 20 \\
\hline 84 & $17 / 03 / 2005$ & 10.66 & 12.65 & 118.67 & 0.83 & -2.82 & 20 \\
\hline 85 & $18 / 03 / 2005$ & 8.38 & 6.82 & 81.38 & 0.65 & 0.91 & 20 \\
\hline 86 & $20 / 03 / 2005$ & 2.03 & 2.71 & 133.5 & 0.16 & -0.84 & 20 \\
\hline 87 & $20 / 03 / 2005$ & 4.57 & 3.57 & 78.12 & 0.36 & 0.64 & 20 \\
\hline 88 & $21 / 03 / 2005$ & 1.01 & 0.72 & 71.29 & 0.08 & 0.21 & 20 \\
\hline 89 & $23 / 03 / 2005$ & 3.04 & 0.61 & 20.07 & 0.24 & 2.19 & 20 \\
\hline 90 & $28 / 03 / 2005$ & 33.52 & 30.21 & 90.13 & 2.61 & 0.7 & 20 \\
\hline 91 & $01 / 04 / 2005$ & 1.77 & 1.22 & 68.93 & 0.14 & 0.41 & 20 \\
\hline 92 & $02 / 04 / 2005$ & 14.47 & 12.06 & 83.34 & 1.13 & 1.28 & 20 \\
\hline 93 & 03/04/2005 & 4.82 & 3.48 & 72.2 & 0.38 & 0.96 & 20 \\
\hline 94 & $04 / 04 / 2005$ & 2.54 & 1.31 & 51.57 & 0.2 & 1.03 & 20 \\
\hline 95 & $05 / 04 / 2005$ & 4.57 & 2.53 & 55.36 & 0.36 & 1.68 & 19 \\
\hline 96 & 06/04/2005 & 0.76 & 0.25 & 32.89 & 0.06 & 0.45 & 20 \\
\hline \multirow[t]{2}{*}{97} & $10 / 04 / 2005$ & 4.57 & 2.73 & 59.74 & 0.36 & 1.48 & 20 \\
\hline & Total: & 1307.90 & 1175.36 & & 102.2 & 31.1 & \\
\hline
\end{tabular}

structures at the respective site. Eleven out of twenty collectors showed temporal trends (collector no. 2,3, 5, 7, 8, 10, $12,15,17,19$ and 20) in throughfall proportions. Among the nine remaining collectors without any temporal trends, five collectors (no. 6, 9, 11, 13 and 18) did not have palm leaves above them. Only one collector (no. 12) without palm tree parts above it showed a slight temporal effect in the beginning of the first study period. Nevertheless, the results show that strong temporal patterns of throughfall volumes were observed beneath palms. Individual palm leaves can act as a natural gutter thanks to the typical, convex form of the petioles, which enables them to collect more water than some 

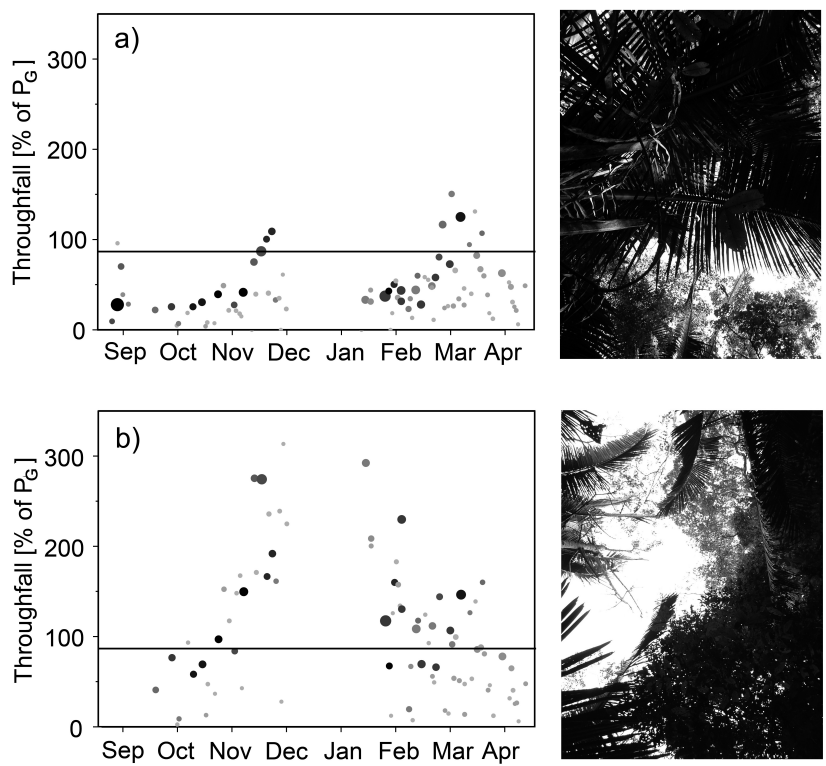

Fig. 3. Temporal patterns of throughfall percentages of incident rainfall for two collectors standing only $5 \mathrm{~m}$ apart from each other. Each event is represented by a dot whose diameter is proportional to rainfall amount. Varying colours from light grey to black illustrate low and high rainfall intensity $\left(I_{10} \mathrm{max}\right)$ values, respectively. The photographs on the right site show the vegetation above these two collectors.

trees of the understory. The water is either diverted to the stems or is funneled towards drip points. As babassu palm leaves grow, they do not just increase in size, but move vertically and horizontally within the canopy due to their own weight gain. If the palm leaves move, the associated drip points move as well and collectors at fixed positions may record a temporal pattern of throughfall percentages. As the growing season of babassu palms falls within the rainy season (Anderson, 1983), these temporal patterns start in October and become more obvious with the beginning of November.

These observations suggest a significant redistribution of water within the canopy and a temporal pattern of this redistribution. Because this redistribution is linked to babassu palms, our findings are pertinent to the understanding of the hydrology of palm-dominated tropical rainforests. Such forests are wide-spread from the eastern to southwestern region of the Amazon basin (Kahn and Granville, 1992). In some regions, this invasive plant forms pure populations in regenerating forest gaps or in abandoned pastures (Lorenzi, 2002). Regional forest surveys do not include subterraneanstemmed palms, whose leaves may reach a length of $9 \mathrm{~m}$. Several authors (Jordan, 1978; Lloyd and Marques, 1988; Manfroi et al., 2004) found that small trees growing in the understory of forests often produce more stemflow than emergent trees with a greater DBH. Consequently, the juvenile palm leaves may be at least as important as leaves from adult
Table 3. Canopy parameters used for interception modeling.

\begin{tabular}{lc}
\hline Parameter & Value \\
\hline$S_{C}$ (canopy capacity per unit cover area) $(\mathrm{mm})$ & $0.74 \pm 0.44$ \\
$c$ (canopy cover) & 0.97 \\
$P_{G}^{\prime}\left(P_{G}\right.$ needed to saturate the canopy) $(\mathrm{mm})$ & 0.33 \\
$\bar{E}_{C}($ mean evaporation rate $)\left(\mathrm{mm} \mathrm{h}^{-1}\right)$ & 0.21 \\
$\bar{R}$ (mean rainfall rate) $\left(\mathrm{mm} \mathrm{h}^{-1}\right)$ & 6.66 \\
$p_{t}$ (rainfall diverted to trunk) & 0.08 \\
$S_{t}$ (trunk storage capacity) $(\mathrm{mm})$ & 0.22 \\
\hline
\end{tabular}

palms concerning the redistribution and uneven input of rainfall to the forest floor. A high density of juvenile palms in the understory as we found for an open tropical rainforest has been reported from other authors for dense rainforests, with individuals reaching heights of 2-4 $\mathrm{m}$ in Colombian Amazonia (Tobón Marin et al., 2000) or 4-5 m in Central Brazilian Amazonia (Lloyd and Marques, 1988). More research with an appropriate sampling design is required to evaluate the importance of small palms in redistributing water and producing locally high inputs of throughfall to the forest floor.

\subsection{The revised Gash model}

Table 3 summarizes the meteorological and canopy input parameters for the interception modeling. Beside canopy cover, the most sensitive parameter in the original and revised Gash model is the canopy capacity per unit cover area, $S_{c}$. The value of $0.74 \pm 0.44 \mathrm{~mm}$ (S.E.) for $S_{c}$ for our site does not differs from the $1.03 \mathrm{~mm}$ reported for the Reserva Jaru, Rondônia (Ubarana, 1996) or from the $1.15 \mathrm{~mm}$ found by Schellekens et al. (1999) for a lowland tropical rainforest in Puerto Rico. But it is lower than the $1.25 \mathrm{~mm}$ and 1.16$1.55 \mathrm{~mm}$ reported for other sites in Amazonia (Ubarana, 1996; Tobón Marin et al., 2000, respectively).

We found a free throughfall coefficient, $\mathrm{p}$, of 0.03 , which is in line with the range of values $(0.03$ to 0.08$)$ obtained by photographic techniques (Lloyd et al., 1988; Ubarana, 1996). These values differ clearly from those determined by more subjective methods (Leyton et al. 1967), which range from 0.23 to 0.32 (Jackson, 1975; Elsenbeer et al., 1994; Schellekens et al., 1999). According to the definition of free throughfall as the amount of water falling through the canopy without striking it, the photographic techniques seem to estimate this proportion better than the other methods, that are influenced by that part of throughfall striking the canopy but reaching the forest floor before the canopy is saturated.

Figure 4 shows the modeled cumulative interception and that calculated from median throughfall (further referred to as "calculated interception") for all events. As discussed in the previous section, negative interception was observed due to the occasional overestimation of average throughfall. 


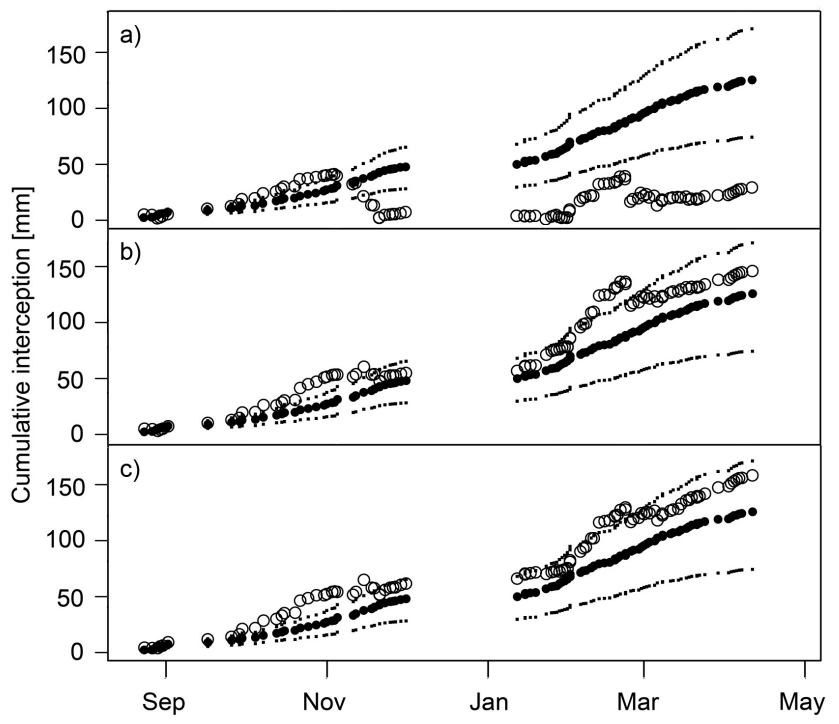

Fig. 4. Cumulative totals of calculated (open circles) and estimated (solid circles) interception for (a) all collectors $(n=20)$, (b) collectors not showing temporal patterns of throughfall percentages $(n=9)$ and for (c) collectors without obvious influence of the palm species Orbignya phalerata $(n=6)$. The dots indicate the uncertainty of the modeled interception resulting from the uncertainty in $S_{C}$.

Beside this overestimation, it is clear from Fig. 4a that the curves of modeled and calculated interception values show a similar increase up to the beginning of November, when the number of events with negative interception increased and the growing season of the babassu palm started. If the assumption is true that the redistribution of rainfall water within the canopy due to the babassu palms is responsible for the difference of the curves of modeled and calculated values, then these differences should not be observed for throughfall medians from collectors with no obvious palm influence or for all collectors which do not show any temporal trends. Figures $4 \mathrm{~b}$ and $\mathrm{c}$ show a better agreement between calculated and modeled values, due to higher calculated interception from mid-November on. The modeled interception does not change within Fig. 4, as the forest parameters used in the model are mean values for our study site. The better fit for collectors without temporal patterns (Fig. 4b) is plausible because the excluded collectors tend towards higher throughfall which is most obvious for collectors 7, 17 and 19 (Fig. 2). In addition, the increase of calculated cumulative interception is greater if fewer collectors with palm influence $(14,4,0$ in Figs. $4 \mathrm{a}, \mathrm{b}$ and c, respectively) are used for the calculations. But the crucial point is that the curves in Figs. $4 \mathrm{~b}$ and $\mathrm{c}$ still show the same trends of calculated interception. Hence, this pattern is unlikely to be induced, but rather amplified, by the presence or absence of drip points associated with palms.

In order to identify causes for the trends in calculated interception, we examined the dependency of interception on rainfall intensity. $\mathrm{I}_{10}$ max instead of $\mathrm{I}_{60} \max$ was used

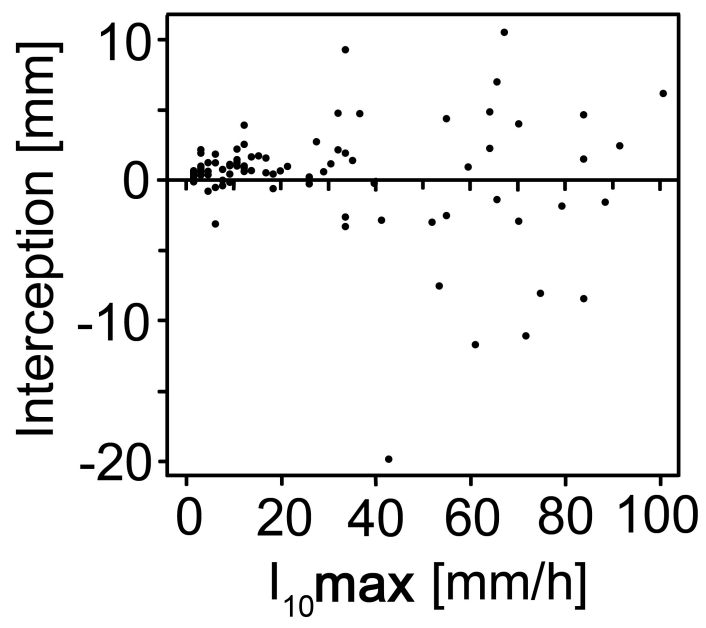

Fig. 5. The relationship between calculated interception and maximum 10 min rainfall intensity $\left(I_{10} \max \right)$.

for this purpose, to include the maximum possible number of events. The relationship of calculated interception and $\mathrm{I}_{10} \max$ (Fig. 5) reveals a rainfall intensity threshold of about $30 \mathrm{~mm} \mathrm{~h}^{-1}$, beyond which interception values show considerable scatter. When cumulative calculated and modeled interception are plotted separately for events with rainfall intensities below and above this threshold (Figs. $6 a$ and b, respectively), the calculated cumulative curve for low intensities shows a uniform trend and falls within the limits of uncertainty of the estimated values. In contrast, the calculated interception for high intensity events shows a variable trend and exceeds the uncertainty limits of the modeled values. As the calculated interception is inferred from the throughfall median, we conclude that for high intensity events it is not adequate to estimate the average throughfall from randomly distributed collectors. Instead, the spatial pattern of drip points and hence of throughfall must be known to estimate a weighted throughfall mean. Such a weighted throughfall mean might improve the estimation of interception also at low rainfall intensities.

It should be kept in mind that any discrepancy between modeled and actual interception derives from the uncertainty not only of $S_{C}$, but also of mean evaporation. Schellekens et al. (1999), using the original Gash model, reported good predictability of cumulated throughfall for a maritime dense tropical rainforest in Puerto Rico as long as the value of $E_{w} / \bar{R}$ was derived from the regression of interception and event rainfall. Although some of their events exceeded our 10-min rainfall intensity threshold (Schellekens, private communication), the authors did not report high negative interception values for single events. Lloyd et al. (1988) stated that the original Gash model performed adequately for a dense tropical rainforest in Central Amazonia, although they did get negative values for interception, which they attributed to the low number of collectors and high spatial variability. 


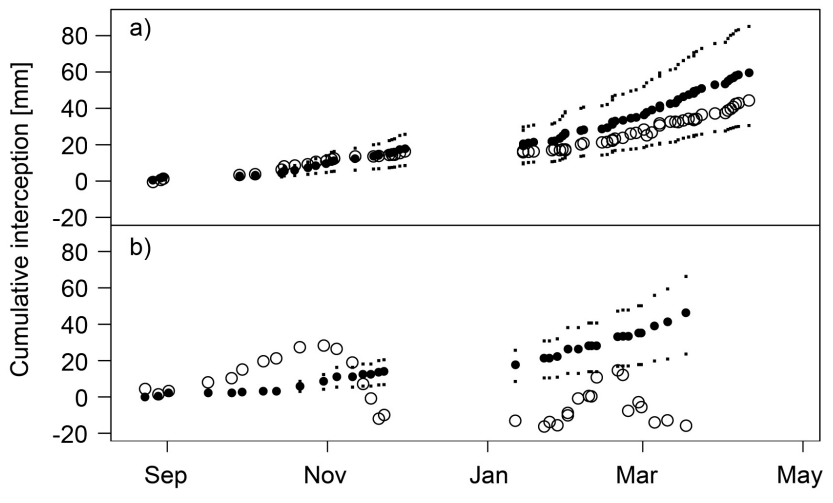

Fig. 6. Cumulative totals of calculated (open circles) and estimated (solid circles) interception for maximum $10 \mathrm{~min}$ rainfall intensities (a) $I_{10} \max \leq 30 \mathrm{~mm} \mathrm{~h}^{-1}$ and (b) $I_{10} \max >30 \mathrm{~mm} \mathrm{~h}^{-1}$ including all collectors $(n=20)$. The dots indicate the uncertainty of the modeled interception resulting from the uncertainty in $S_{C}$.

It would be interesting to know if the negative interception values found by Lloyd et al. (1988) were associated to maximum 10-min intensities greater than $30 \mathrm{~mm} \mathrm{~h}^{-1}$.

\section{Conclusions}

Tropical rain forest are the most difficult forest type in which to measure throughfall, stemflow and consequently to determine interception. We calculated a total measured throughfall volume of $89.8 \pm 5.6 \%$ of incident rainfall.

The results of our experiment suggest furthermore that in open tropical rainforests with high palm densities, the palms play an important role in generating dynamic spatial variability of throughfall. At our study site, the babassu palm (Orbignya phalerata) is the most important species responsible for high redistribution of rainfall within the canopy due to their conducive morphology and their high stem density. The spatial pattern of water input to the forest floor shows temporal patterns, which appear to be controlled by babassu palms and their leaf growth. Furthermore, the relationship of 10-min rainfall intensity and interception revealed a threshold of $30 \mathrm{~mm} \mathrm{~h}^{-1}$ above which the calculated interception is highly variable. A comparison of calculated and modeled interception showed that this variability can be greatly amplified by funneling and shading effects of palms (Fig. 4). We conclude that for high intensity events it is not possible to estimate interception from median throughfall. If the spatial pattern of throughfall is known, a weighted mean throughfall might yield better results.

As the babassu palm is common throughout the Amazon basin (Kahn and Granville, 1992) in upland as well as in seasonal swamp forests, the role of pronounced redistribution of rainfall within the canopy due to these palms should be considered in future research. As the high intensity events responsible for the large variability in throughfall tend to be of high magnitude as well, our results are relevant for the hydrology not only of open tropical rainforest dominated by palms, but perhaps as well for dense tropical rainforest with a high density of juvenile palms in the understory.

Acknowledgements. This study was partially supported by the US National Science grant no. DEB-0315656 and the LBA program grant NCC5-285 to the Marine Biological Laboratory. H. Elsenbeer and J. de Moraes were supported by PROBRAL, a DAAD and CAPES-financed program. We all want to thank the Schmitz family for logistical support and the opportunity to work on their land.

Edited by: N. Romano

\section{References}

Anderson, A. B.: The biology of Orbignya martiana (Palmae), tropical dry forest dominant in Brazil, Ph.D., University of Florida, Gainesville, Florida, 1983.

Beier, C., Hansen, K., and Gundersen, P.: Spatial variability of throughfall fluxes in a spruce forest, Environ. Pollut., 81, 257267, 1993.

Chuyong, G. B., Newbery, D. M., and Songwe, N. C.: Rainfall input, throughfall and stemflow of nutrients in a central African rain forest dominated by ectomycorrhizal trees, Biogeochem., 67, 73-91, 2004.

Dykes, A. P.: Rainfall interception from a lowland tropical rainforest in Brunei, J. Hydrol., 200, 260-279, 1997.

Elsenbeer, H., Cassel, D. K., and Zuniga, L.: Throughfall in the terra firme forest of western Amazonia, J. Hydrol., 32, 30-45, 1994.

Filoso, S., Williams, M. R., and Melack, J. M.: Compostion an deposition of throughfall in a flooded forest archipelago (Negro River, Bazil), Biogeochem. 45, 169-195, 1999.

Ford, E. and Deans, J.: The effects of canopy structure on stemflow, throughfall and interception loss in a young Sitka spruce plantation, J. Appl. Ecol., 15, 905-917, 1978.

Gash, J. H. C.: An analytical model of rainfall interception by forests, Q. J. Roy. Meteo. Soc., 105, 43-55, 1979.

Gash, J. H. C. and Morton, A. J.: An application of the Rutter Model to the estimation of the Interception Loss from Thetford Forest, J. Hydrol., 38, 49-58, 1978.

Gash, J. H. C., Lloyd, C. R., and Lachaud, G.: Estimating sparse forest rainfall interception with an analytical model, J. Hydrol., 170, 79-86, 1995.

Hall, R.: Interception loss as a function of rainfall and forest types: stochastic modelling for tropical canopies revisited, J. Hydrol., 280, 1-12, 2003.

Hanchi, A. and Rapp, M.: Stemflow determination in forest stands, Forest Ecol. Manag., 97, 231-235, 1997.

Helvey, J. D. and Patric, J. H.: Design criteria for interception studies, Int. Assoc. Hydrol. Sci. Bull., 67, 131-137, 1965.

Herwitz, S. A.: Raindrop impact and water flow on the vegetative surfaces of trees and the effects on stemflow and throughfall generation, Earth Surf. Proc. Land., 12, 425-432, 1987.

Herwitz, S. R. and Slye, R. E.: Spatial variability in the interception of inclined rainfall by a tropical rainforest canopy, Selbyana 13, 62-71, 1992. 
Hoaglin, D. C., Mosteller, F., and Tukey, J.: Understanding Robust and Exploratory Data Analysis, Wiley, New York, 2000.

Holder, C. D.: Rainfall interception and fog precipitation in a tropical montane cloud forest of Guatemala, Forest Ecol. Manag., 190, 373-384, 2004.

Huber, A. and Iroume, A.: Variability of annual rainfall partitioning for different sites and forest covers in Chile, J. Hydrol., 248, 7892, 2001.

Isotta, C. A. L., Carneiro, J. M., Kato, H. T., and Barros, R. J. L.: Projeto Província Estanífera de Rondônia, in: Porto Velho: DNPM/CPRM, 1978.

Jackson, I. J.: Problems of throughfall and interception assessment under tropical forest, J. Hydrol., 12, 234-254, 1971.

Jackson, I. J.: Relationships between rainfall parameters and interception by tropical rainforest, J. Hydrol., 24, 215-238, 1975.

Jetten, V. G.: Interception of tropical rainforest: performance of a canopy water balance model, Hydrol. Process., 10, 671-685, 1996.

Jordan, C. F.: Stem flow and nutrient transfer in a tropical rain forest, Oikos, 31, 257-263, 1978.

Kahn, F. and Granville, J.-J. d.: Palms in Forest Ecosystems of Amazonia, Springer, Berlin, 1992.

Keim, R. F., Skaugset, A. E., and Weiler, M.: Temporal Persistence of Spatial Patterns in Throughfall, J. Hydrol. 314, 263-274, 2005.

Leal, J. W. L., Silva, G. H., dos Santos, D. B., Texeira, W., Lima, M. I. C., Fernandes, C. A. C., and Pinto, A. d. C.: Geologia - Folha SC. 20, in: Projeto Radambrasil, Porto Velho, 219-355, 1978.

Leyton, L., Reynolds, E. R. C., and Thompson, F. B.: Rainfall interception in forest and moorland, in: Forest hydrology: proceedings of a national science foundation advanced science seminar, edited by: Sopper, W. E. and Lull, H. W., Oxford, Pergamon Press, 163-178, 1967.

Link, T. E., Unsworth, M., and Danny, M.: The dynamics of rainfall interception by a seasonal temperate rainforest, Agr. Forest Meteorol., 124, 171-191, 2004.

Liu, W. Y., Fox, J. E. D., and Xu, Z. F.: Nutrient budget of a montane evergreen broad-leaved forest at Ailao Mountain National Nature Reserve, Yunnan, southwest China, Hydrol. Process., 17, 1119-1134, 2003.

Lloyd, C. R. and Marques, A. O.: Spatial variability of throughfall and stemflow measurements in Amazonian rainforest, Agr. Forest Meteorol., 42, 63-73, 1988.

Lloyd, C. R., Gash, J. H. C., Shuttleworth, W. J., and Marques, F. A. O.: The measurement and modelling of rainfall interception by Amazonian rain forest, Agr. Forest Meteorol., 42, 277-294, 1988.

Loescher, H. W., Powers, J. S., and Oberbauer, S. F.: Spatial variation of throughfall volume in an old-growth tropical wet forest, Costa Rica, J. Trop. Ecol., 18, 397-407, 2002.

Lorenzi, H.: Brazilian Trees: A Guide to the Identification and Cultivation of Brazilian Native Trees, Instituto Plantarum, Nova Odessa, SP, 2002.

Manfroi, O. J., Koichiro, K., Nobuaki, T., Masakazu, S., Nakagawa, M., Nakashizuka, T., and Chong, L.: The stemflow of trees in a Bornean lowland tropical forest, Hydrol. Process., 18, 24552474, 2004.

Munishi, P. K. T. and Shear, T. H.: Rainfall interception and partitioning in afromontane rain forests of the Eastern Arc Mountains,
Tanzania: Implications for water conservation, J. Trop. For. Sci., 17, 355-365, 2005.

Peixoto de Melo, D., da Costa, R. C., and Natali Filho, T.: Geomorfologia - Folha SC. 20, in: Projeto Radambrasil, Porto Velho, 187-250, 1978.

Pequeno, P. L. d. L., Vieira, A. H., and Martins, E. P.: Desmatamento e biodiversidade - uma pequena visão do estado de Rondônia, on: http://www.arvore.com.br/artigos/htm_2002/ ar2208_2.htm, 2002.

Roberts, J. M., Cabral, O. M. R., Costa, J. P. R., McWilliam, A.L. C., and Sá, T. D. A.: An overview of the leaf area index and physiological measurements during ABRACOS, in: Amazonian Deforestation and Climate, edited by: Gash, J. H. C., Nobre, C. A., Roberts, D. A., and Victoria, R. L., Chichester, Wiley \& Sons Ltd, 287-306, 1996.

Rowe, L. K.: Rainfall interception by an evergreen beech forest, Nelson, New Zealand, J. Hydrol., 66, 143-158, 1983.

Rutter, A. J., Kershaw, K. A., Robins, P. C., Morton, J.: A predictive model of rainfall interception in forests: I. Derivation of the model from observations in a plantation of Corsican pine, Agr. Forest Meteorol., 9, 367-380, 1971.

Sachs, L.: Applied statistics: a handbook of techniques, Springer, New York, 1984.

Savenije, H. H.: The importance of interception and why we should delete the term evapotranspiration from our vocabulary, Hydrol. Process., 18, 1507-1511, 2004.

Shapiro, S. S. and Wilk, M. B.: An analysis of variance test for normality (complete samples), Biometrika, 52:, 591-611, 1965.

Schellekens, J., Scatena, F. N., Bruijnzeel, L. A., and Wickel, A. J.: Modelling rainfall interception by a lowland tropical rain forest in northeastern Puerto Rico, J. Hydrol., 225, 168-184, 1999.

Schroth, G., Da Silva, L. F., Wolf, M.-A., Teixeira, W. G., and Zech, W.: Distribution of throughfall and stemflow in multistrata agroforestry, perennial monoculture, fallow and primary forest in central Amazonia, Brazil, Hydrol. Process., 13, 1423 1436, 1999.

Sinun, W., Meng, W. W., Douglas, I., and Spencer, T.: Throughfall, stemflow, overland flow and throughflow in the Ula Segama rain forest, Sabah, Malaysia, Philosophical Transactions of the Royal Society, Series B, 335, 389-395, 1992.

Soil Survey Staff: Soil Taxonomy - A Basic Sysstem of Soil Classification for Making and Interpreting Soil Surveys, US Government Printing Office, Washington, DC, 1999.

Tobón Marin, C., Bouten, W., and Sevink, J.: Gross rainfall and its partitioning into throughfall, stemflow and evaporation of intercepted water in four forest ecosystems in western Amazonia, J. Hydrol., 237, 40-57, 2000.

Ubarana, V. N.: Observations and modelling of rainfall interception at two experimental sites in Amazonia, in: Amazonian Deforestation and Climate, edited by: Gash, J. H. C., Nobre, C. A., Roberts, D. A., and Victoria, R. L., Chichester, Wiley \& Sons Ltd, 151-162, 1996.

Xiao, Q., McPherson, E. G., Ustin, S. L., and Grismer, M. E.: A new approach to modeling tree rainfall interception, J. Geophys. Res., 105, 173-188, 2000. 